\title{
Financing Supply of Islamic Banking During COVID-19 Outbreak in Indonesia
}

\author{
Muhammad Anif Afandi \\ Universitas Muhammadiyah Metro, Indonesia
}

\begin{abstract}
Article History
Received: May 26 $6^{\text {th }}, 2021$ Revised: May 29th, 2021 Accepted: June 09th 2021
\end{abstract}

\begin{abstract}
Corresponding author:

E-mail: m.anifafandi@ummetro ac.id

This study aimed to analyze the factors that affected the financing supply of Islamic banking during the COVID-19 outbreak in Indonesia. The variable of financial performances of Islamic banking such as Return on Assets (ROA), Capital Adequacy Ratio (CAR), Financing to Deposit Ratio (FDR), and NonPerforming Financing (NPF) was used as the independent variables. Meanwhile, the impact of the COVID-19 pandemic was analyzed through a dummy variable. Furthermore, each of the independent variables and the dummy variable was tested its influence on the dependent variable, the financing supply of Islamic banking, by using a proxy of the total financing. Ordinary Least Square (OLS) with double log model used as a data analysis technique, and the results showed that the variable of ROA had a positive but not significant effect on the financing supply. Variable CAR and FDR each showed a negative and not significant effect on the financing supply. In contrast, the variable of NPF showed a negative and significant effect on the financing supply. Meanwhile, the COVID-19 pandemic contributed to giving a positive and significant difference effect to the financing supply than before the presence of COVID-19 in Indonesia. The results of this study proved that the phenomenon of the credit crunch in Islamic banking relative could be addressed during the COVID-19 outbreak in Indonesia.
\end{abstract}

Keywords: COVID-19. Financing Supply, Indonesia, Islamic Banking

\section{Introduction}

\subsection{Background}

Since established as a global pandemic by the World Health Organization (WHO) in March 2020, Coronavirus Disease 2019 (COVID-19) not only have an impact on the health problems, but also spread to the financial sector. According to the World Bank (2020), the financial sectors face a tough challenge during pandemic COVID-19 outbreak which has the

How to cite:

Afandi, M. A. (2021). Financing Supply of Islamic Banking During COVID-19 Outbreak in Indonesia. Journal of Islamic Economic and Business Research, 1(1), 114-124. DOI:10.18196/jiebr.v1i1.11807 
potential for the occurrence of the financial crisis due to the main activity of the financial sector in particular lending experienced a slowdown caused by the credit demand decreased in households or MSMEs due to the restrictions of human activity (lockdown) which leads to a decrease of the profitability of the business.

Indonesia is one of the countries which has been affected by the presence of COVID-19 pandemic since the existence of the first positive case in March 2020. Based on the report of Bank Indonesia (2021), the activity of banking intermediation in Indonesia has experienced weak performance caused by the contraction of credit amounted to 2.41 percent (y-o-y) at the end of December 2020 although Third-Party Funds (DPK) actually increased by 11.11 percent (y-o-y). The weak activity of banking intermediation is caused by the low demand for credit and the prudence of banks in lending to the consideration of credit risk that is high during COVID-19 pandemic, which is characterized by an increasing in the ratio of nonperforming loans amounted to 2.53 percent in December 2020 compared to December 2019 (Bank Indonesia, 2021).

Based on the above explanation, the condition of the banks in Indonesia during COVID-19 pandemic experience the phenomenon of the credit crunch that is a condition of declining in lending due to the declining in demand for credit and the reluctance of banks to extend credit because the precautionary principle that is high during COVID-19 pandemic (Bank Indonesia, 2021). These circumstances if left protracted course may affect the instability of the financial system and the economy more broadly. Then, this study wants to know from the perspective of micro-prudential which is through the financial performances of Islamic banking in Indonesia, which tested its influence to the financing supply with a proxy of the total financing as a reflection of the credit crunch. The selection of Islamic banks as the object of research is based that the sector of Islamic banking financing still accounted for the numbers of positive growth despite a slowdown amid COVID-19 pandemic in Indonesia throughout the year 2020, so that this study wants to prove those data scientifically (Bank Indonesia, 2020).

In addition, as the foundation in this study, it is necessary to conduct analysis of the extent to which this research topic has been reviewed by previous researchers. Based on the searches conducted, it was found that previous studies with similar topics were still tends to be quite limited as it were done by Çolak \& Öztekin (2019) and Hasan, Politsidis \& Sharma (2020). Both of these studies have not been using the Islamic banking as an object of study but rather use the data of the conventional bank with the type of panel data among several countries around the world. Then, the data usage of Islamic banking as the research object in this study is expected to close the gap study or be a novelty in this study.

\subsection{Objective}

Based on the background above, it is known that previous studies with similar topics were still likely to be limited and not using Islamic banking as the research object, so that this study, which aims to close the gap of the research and to analyze the factors that affect the financing supply of Islamic banking amid the COVID-19 outbreak in Indonesia. 


\section{Literature Review}

\subsection{Background Theory}

Credit or financing supply is the ability and willingness of banks in providing financing to the customers (Manaresi \& Pierri, 2018). Financing supply plays an important role for the activity of banking intermediation. Banking with the conditions of good financial performances and supported with good quality lenders will determine the amount of bank lending to the customers (Imran \& Nishat, 2013; Altavilla et al., 2018; Busmante, Cuba \& Nivin, 2019).

However, in the time of pandemic COVID-19 outbreak, banking assessed do the credit crunch or the behavior of the limiting distribution of credit by using the strict prudential principles because the credit risk that are rated high enough during COVID-19 pandemic (Barua \& Barua, 2021). Therefore, it is necessary to do a special treatment given the credit crunch because it can affect the decreasing in the productivity of a company that can have an impact on the declining in the economic growth of a country like that occur after the onset of the financial crisis in 2008 by the OECD countries (Manaresi \& Pierri, 2018).

\subsection{Previous Studies}

Previous studies in accordance with the context of this study were done by Colak \& Öztekin (2019) and Hasan, Politsidis \& Sharma (2020). Çolak \& Öztekin (2019) conducted a study on the impact of COVID-19 pandemic against the bank lending in 125 countries by the method of difference-in-difference and conclude that bank lending was weak in the country that was experiencing a health crisis due to COVID-19 pandemic. Factors that affect bank lending depended on the financial condition of the bank, market structure, regulations and other.

Meanwhile, Hasan, Politsidis \& Sharma (2020) conducted a study on bank lending during COVID-19 pandemic and summing up the results of study that the financing syndicated globally has increased the cost which was triggered from the increasing in the exposure of banks and corporate borrowers of funds that can trigger the occurrence of bad credit.

Another study that has discussed of this topic conducting before COVID-19 pandemic, such as studies conducted by Chernykh \& Theodossiou (2011), Imran \& Nishat (2013), Malede (2014) and Alkhazaleh (2017).

The studies that have been described above where appropriate with the context of this study were not specifically use Islamic banking as the research object, then this study sought to accommodate it to be able to close the gap of the research and make the novelty. In addition, the use of Islamic banks as the object of this research is based on the report of Bank Indonesia (2020), which stated that the financing of Islamic banking still accounted for the numbers of positive growth amid COVID-19 pandemic in Indonesia, then this study is to prove the data scientifically.

\subsection{Conceptual Framework}

This study uses independent variables in the form of financial performance ratios of Islamic banks in the form of ROA, CAR, FDR and NPF. In addition, this study also uses a dummy 
variable that is COVID-19 pandemic with the notation $0=$ before COVID-19 and $1=$ during the occurrence of COVID-19 in Indonesia, which is characterized by the first positive case in March 2020. Whereas, the dependent variable used is the financing supply by using a proxy of the total financing. Further, each independent variables and the dummy variable are connected with the dependent variable to analyze the factors that affect the financing supply of Islamic banks during COVID-19 pandemic in Indonesia. In more detail, the relationship of each of these variables is described in the conceptual framework as follows:

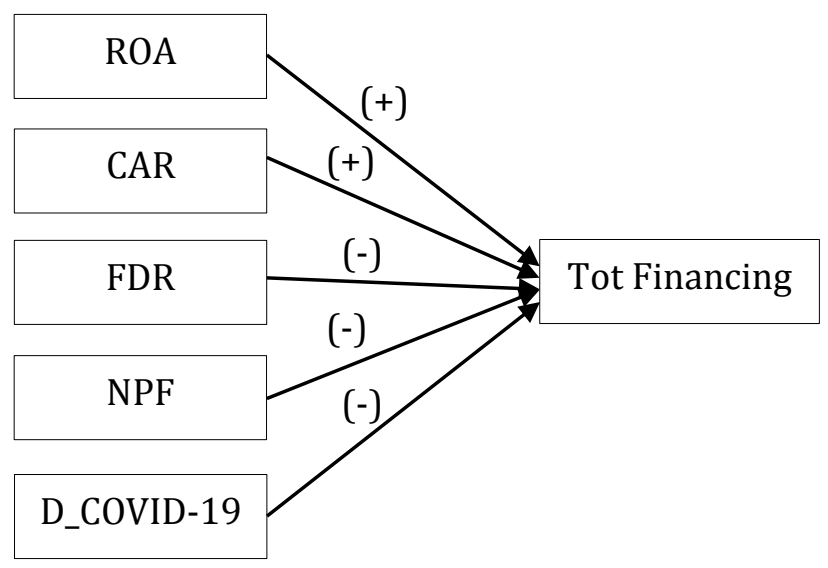

Figure 1. Conceptual Framework

Source: Author

\section{Methodology}

\subsection{Data}

This study is a type of quantitative research to analyze the factors that affect the financing supply of Islamic banks during COVID-19 outbreak in Indonesia. The type of data used in this study is secondary data with the monthly period that is collected through the publication of the Statistics of Islamic Banking, the Financial Services Authority, the Republic of Indonesia during the period January, 2018 - January 2021. This study uses several types of variables, independent variable, dummy variable and the dependent variable. Independent variable used are the financial performances of Islamic banking such as ROA, CAR, FDR and NPF. Dummy variable used is a dummy COVID-19 pandemic with the notation $0=$ before COVID-19 and $1=$ during the occurrence of COVID-19 in Indonesia, which is characterized by the first positive case in March 2020. Whereas, the dependent variable used is the financing supply by using a proxy of the total financing.

\subsection{Model Development}

After data collection, further processing and analysis of data. Processing techniques and data analysis used in this study is Ordinary Least Square (OLS). OLS method used in this study is the double log model which is done by transforming all variables used. According to Nachrowi \& Usman (2018), the double log model used as a model to minimize the weaknesses of the OLS model that is very difficult to interpret the value of the intercept that 
can result in interpretation which is not in accordance with the real conditions. The regression model used in this study is as follows:

$Y_{i}=b_{0}+b_{1} X_{1 i}+b_{2} X_{2 i}+b_{3} X_{3 i}+b_{4} X_{4 i}+b_{5} X_{5 i}+e_{i}$

The OLS double log model:

$\ln Y_{i}=b_{0}+\ln b_{1} X_{1 i}+\ln b_{2} X_{2 i}+\ln b_{3} X_{3 i}+\ln b_{4} X_{4 i}+\ln b_{5} X_{5 i}+e_{i}$

where:

$Y_{i} \quad=$ total financing of Islamic Banking in Indonesia (Billion Rupiah)

${ }_{i}=$ the number of observations (37 time series data from January 2018 to January 2021)

$b_{0} \quad=$ constant

$X_{1 i} \quad=$ Return on Assets (Percent)

$X_{2 i} \quad=$ Capital Adequacy Ratio (Percent)

$X_{3 i} \quad=$ Financing to Deposit Ratio (Percent)

$X_{4 i} \quad=$ Non-Performing Financing (Percent)

$X_{5 i} \quad=$ dummy COVID-19 $(0=$ before COVID-19 and $1=$ during the occurrence of COVID19 in Indonesia, which is characterized by the first positive case in March 2020)

$e_{i} \quad=$ error term

\subsection{Method}

This study uses OLS as data processing techniques and analysis. According to Sumantri \& Yudawisastra (2019), OLS is a method of statistical testing that aims to analyze the influence of independent variables to the dependent variable by using at least two independent variables as a predictor factor. Before the results of data processing can be interpreted, then it needs to be done the classical assumption test such as multicollinearity, heteroscedasticity and autocorrelation to guarantee that the resulting model has a meaning or robust (Alkhazaleh, 2017). Hypothesis statistic used in the OLS is as follows:

$\mathrm{H}_{0}: \mathrm{b}_{1}, \mathrm{~b}_{2}, \mathrm{~b}_{3}, \mathrm{~b}_{4}, \mathrm{~b}_{5}=0(\mathrm{X}$ does not affect $\mathrm{Y})$

$H_{1}: b_{1}, b_{2}, b_{3}, b_{4}, b_{5} \neq 0(X$ affect $Y)$

\section{Results and Analysis}

\subsection{Results}

After the collection and processing of the data, output OLS testing that is produced can be shown in a table as follows:

Table 1. The Output of Ordinary Least Square (OLS) Test

\begin{tabular}{ccccc}
\hline Variable & Coefficient & Std. Error & t-Statistic & Prob. \\
\hline C & 14.71546 & 1.579148 & 9.318607 & 0.0000 \\
LOGROA & 0.039746 & 0.033166 & 1.198408 & 0.2398 \\
LOGCAR & -0.135717 & 0.179428 & -0.756387 & 0.4551 \\
LOGFDR & -0.386950 & 0.344633 & -1.122788 & 0.2701 \\
LOGNPF & -0.304375 & 0.078127 & -3.895911 & 0.0005 \\
D_COVID & 0.108584 & 0.015587 & 6.966400 & 0.0000 \\
R-squared & 0.865106 & & & \\
Adjusted R-squared & 0.843349 & & & \\
F-statistic & 39.76208 & & &
\end{tabular}


Financing Supply of Islamic Banking during COVID-19 Outbreak in Indonesia

Muhammad Anif Affandi

Page : 114-124

Prob(F-statistic) $\quad 0.000000$

Source: Computed by Author (2021)

Based on the above table, can be written OLS model used in this study as follows:

Tot Financing $=14.715+0.039 \mathrm{ROA}-0.136 \mathrm{CAR}-0.387 \mathrm{FDR}-0.304 \mathrm{NPF}$

+0.109 D_COVID19

From the equation OLS above can be interpreted as follows:

a. The constant value of 14.715 meaning that the average financing supply which has distributed by the Islamic banking before the pandemic COVID-19 outbreak in Indonesia in March 2020.

b. The value of the $b_{1}$ variable ROA of 0.039 meaning that every increasing in ROA of Islamic banks by 1 percent, it will increase the financing supply of 0.039 percent. Based on the output of the OLS testing is known that the p-value of $0.2398>\alpha 0.05$, then the corresponding hypothesis can be decided that $\mathrm{H}_{0}$ is accepted or it can be concluded that ROA has a positive but not significant effect to the financing supply of Islamic banks in Indonesia.

c. The value of $b_{2}$ variable CAR by -0.136 meaning that every increasing in CAR of Islamic banks amounted to 1 percent, it will decrease the financing supply of 0.136 percent. Based on the output of the OLS testing is known that the p-value of $0.4551>\alpha 0.05$, then the corresponding hypothesis can be decided that $\mathrm{H}_{0}$ is accepted or it can be concluded that CAR has a negative and not significant effect to the financing supply of Islamic banks in Indonesia.

d. The value of $b_{3}$ variable FDR by -0.387 meaning that that every increasing in FDR of Islamic banks amounted to 1 percent, it will decrease the financing supply of 0.387 percent. Based on the output of the OLS testing is known that the p-value of $0.2701>\alpha$ 0.05 , then the corresponding hypothesis can be decided that $\mathrm{H}_{0}$ is accepted or it can be concluded that FDR has the negative and not significant effect to the financing supply of Islamic banks in Indonesia.

e. The value of $b_{4}$ variable NPF by -0.304 meaning that every increasing in NPF amounted to 1 percent, it will decrease the financing supply of 0.304 percent. Based on the output of OLS testing is known that the p-value of $0.0005<\alpha 0.05$, then the corresponding hypothesis can be decided that the $\mathrm{H}_{0}$ is rejected, or it can be concluded that NPF has negative and significant effect to the financing supply of Islamic banks in Indonesia.

f. The value of $b_{5}$ dummy variable of COVID-19 pandemic by 0.109 meaning that the average financing supply of Islamic banks during pandemic COVID-19 outbreak in Indonesia is higher than the financing supply of Islamic banks before pandemic COVID19 outbreak happening Indonesia in March 2020 as much as 0.109 percent. Based on the output of OLS testing is known that the p-value of $0.0000<\alpha 0.05$, then the corresponding hypothesis can be decided that the $\mathrm{H}_{0}$ is rejected, or in other words it can be concluded that there are positive and significant differences between the financing supply of Islamic banks during the onset of the pandemic COVID-19 outbreak in Indonesia compared to the financing supply of Islamic banks before the onset of the pandemic COVID-19 outbreak in Indonesia. 
g. Based on F-statistic testing is known the probability value of F-statistic of $0.000000<\alpha$ 0.05 which means that simultaneously all the variables of financial performance of Islamic banks significantly influence to the financing supply of Islamic banks in Indonesia.

h. The value of R-squared of 0.865 meaning that the independent variables used in this study are able to explain the variation of its dependent variable of 86.5 percent, while the rest of 13.5 percent is explained by other variables that are not taken into account in the model of this study.

\subsection{Robustness Test}

To make sure that the OLS model generated above has meaning or robust, it needs to be done the classical assumption test consisting of multicollinearity, heteroscedasticity and autocorrelation with the following output:

Table 2. The Output of Multicollinearity Test

\begin{tabular}{lccccc}
\hline & LOGROA & LOGCAR & LOGFDR & LOGNPF & D_COVID \\
\hline LOGROA & 1 & 0.506 & 0.135 & -0.705 & 0.121 \\
LOGCAR & 0.506 & 1 & 0.014 & -0.719 & 0.458 \\
LOGFDR & 0.135 & 0.014 & 1 & 0.001 & -0.219 \\
LOGNPF & -0.705 & -0.719 & 0.001 & 1 & -0.464 \\
D_COVID & 0.121 & 0.458 & -0.219 & -0.464 & 1 \\
\hline
\end{tabular}

Source: Computed by Author (2021)

Table above explains that the value of correlation among the independent variables used in the study none of which exceed 0.8 , then it can be concluded that this study is free from the problems of multicollinearity and can be continued by testing another classical assumption test which is heteroscedasticity.

Table 3. The Output of Heteroskedasticity Test

\begin{tabular}{llll}
\hline Heteroskedasticity Test: & Breusch-Pagan-Godfrey & \\
\hline F-statistic & 2.080473 & Prob. F(5,31) & 0.0946 \\
Obs*R-squared & 9.296267 & Prob. Chi-Square(5) & 0.0978 \\
Scaled explained SS & 4.317854 & Prob. Chi-Square(5) & 0.5046 \\
\hline
\end{tabular}

Source: Computed by Author (2021)

From the above table it can be seen that based on the heteroscedasticity testing by using the method of Breusch-Pagan-Godfrey, a probability value of chi-square of $0.0978>\alpha 0.05$ meaning that all the residuals have the same variant or called homoskedasticity.

Table 4. The Output of Autocorrelation Test

\begin{tabular}{lrll}
\hline Breusch-Godfrey Serial Correlation LM Test: & \\
\hline F-statistic & 1.844472 & Prob. F(9,22) & 0.1163 \\
Obs*R-squared & 15.91205 & Prob. Chi-Square(9) & 0.0687 \\
\hline \multicolumn{4}{c}{ Source: Computed by Author (2021) }
\end{tabular}

The last classical assumption test is autocorrelation which aimed to determine the correlation between the residuals that often occur on the type of time series data. Based on the above table, it is known that the results of the autocorrelation test with the method of Breusch-Godfrey Serial Correlation LM Test produces a probability value of chi-square of 
$0.0687>\alpha 0.05$ which means that the residuals contain no correlation, then it has been freed from the problem of autocorrelation.

Based on the results of the classical assumption test consisting of multicollinearity, heteroscedasticity and autocorrelation above, it can be concluded that the regression models generated in this study has met all of the tests, so that the regression model in this study can be said to have been valid as a predictor, which can then be carried out the analysis of the results of this study.

\subsection{Analysis}

From the results of OLS test is known that the variable of ROA has a positive but not significant effect to the financing supply. That result is not in accordance with the results of study conducted by Alkhazaleh (2017) which stated that the ROA had positive and significant impact on commercial banks lending.

Another result of OLS test is known that the variable of CAR has a negative and not significant effect to the financing supply. That result support the results of study conducted by Chernykh \& Theodossiou (2011) which stated that the bank capital determined the distribution of credit in the long term or in other words the smaller of the capital of the bank then it will negatively affect the distribution of credit.

For variable FDR, from the results of OLS test is known that the variable of FDR has a negative and not significant effect to the financing supply. That result support the results of study conducted by Alkhazaleh (2017). However, that result is not in accordance with the results of studies conducted by Imran \& Nishat (2013); Malede (2014) which stated that the bank's liquidity had a positive and significant effect to the distribution of bank credit.

Then, from the results of OLS test is known that the variable of NPF has a negative and significant effect to the financing supply. That result support the results of study conducted by Alkhazaleh (2017). However, that result is not in accordance with the results of study conducted by Malede (2014) which stated that credit risk had a positive and significant effect to the distribution of bank credit.

Meanwhile, from the results of OLS test known that the dummy variable of COVID-19 has a positive and significant effect to the financing supply. That result is not in accordance with the results of study conducted by Colak \& Öztekin (2019) which stated that the COVID-19 decreased the distribution of bank lending although with the different level in each country depending on the level of a health crisis occurs.

Based on the results above, it can be said that the Islamic banking in Indonesia is still likely to be able to handle the impact of COVID-19 pandemic on the aspect of financing supply which is evidenced by a positive and significant influence of dummy variable (COVID-19) to the financing supply. However, despite Islamic banking looks applying the precautionary principle due to high credit risk, which is high enough in the time of COVID-19 pandemic, so that despite an increasing in financial performances for example, ROA, CAR and FDR but not necessarily followed by an increasing in the financing distribution. 


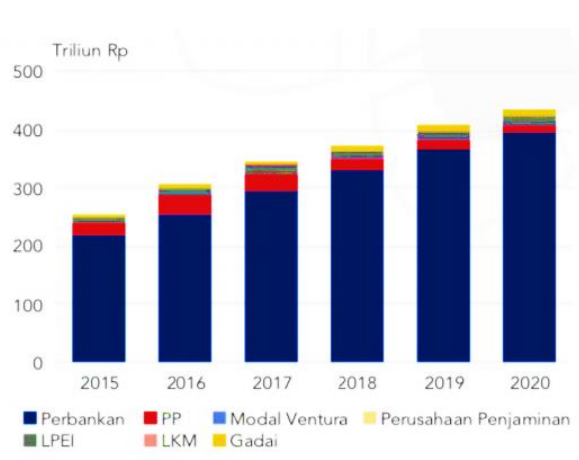

(a)

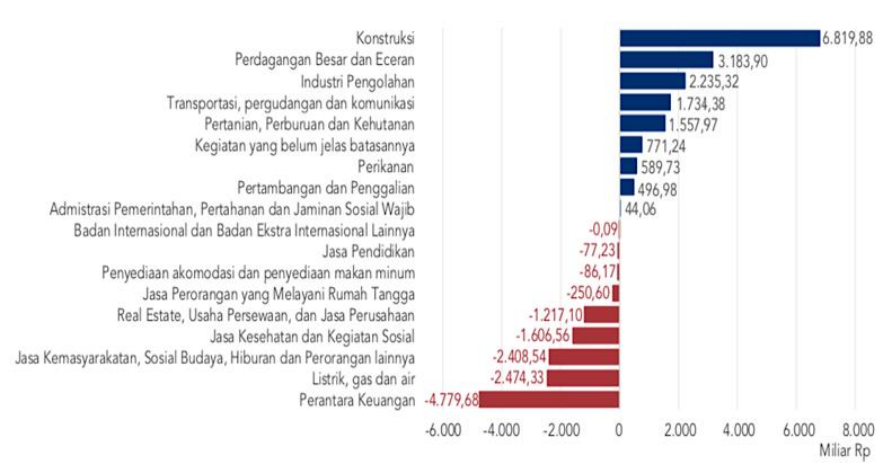

(b)

Figure 2. The Development of Financing in Islamic Financial Services Industry in Indonesia Source: Bank Indonesia (2020)

The figures above prove empirically that based on the report of Bank Indonesia (2020), the financing of Islamic banking is still showing positive growth amid the growth of negative credit of conventional banking amid the COVID-19 pandemic in Indonesia. In 2020, the Islamic banks disbursed of IDR 434,53 Trillion, where the amount was increased by 6.27 percent compared to the amount of financing provided throughout the year 2019 in the amount of IDR 395,69 Trillion.

Improved financing of Islamic banks in Indonesia according to Bank Indonesia (2020), supported by financing disbursed in nine industrial sectors, especially in the agricultural and fisheries sectors. These conditions reflect that already start to link and match between supply and demand which is Islamic banking and financing needs by the industry. In addition, the positive performance of Islamic bank financing amid the COVID-19 pandemic also indicates the success of the banking policy of both macro-prudential and microprudential issued by the banking regulators in Indonesia.

However, although the performance of Islamic bank financing is still positive amid the COVID-19 pandemic in Indonesia, the behavior of Islamic banking has proven to be very cautious in extending financing to its customers. This happens due to the high perception of the bank against the risk to the future as the impact of the COVID-19 pandemic which is not yet over (Bank Indonesia, 2021). In addition, the behavior of the prudence of the bank also carried out by considering of the increasing of the ratio of non-performing loans during COVID-19 pandemic although it is still in the threshold of safe. However, it needs to be anticipated and carried out a serious study about the ability to pay financing by the customer to avoid a credit crunch due to the prolonged pandemic (Bank Indonesia, 2021).

\section{Conclusion and Recommendation}

\subsection{Conclusion}

Based on the results and analysis that has been done, it can be concluded that the variable of ROA has a positive but not significant effect to the financing supply. The variable of CAR and FDR, respectively have negative and not significant effect to the financing supply. Meanwhile, the variable of NPF known that has a negative and significant effect to the 
financing supply. For the dummy variable, the results of this study prove that the COVID-19 pandemic gives a positive and significant effect to the financing supply.

Through the results of this study, successfully carried out a proof that the phenomenon of credit crunch relatively does not happen in Islamic banks amid the COVID-19 pandemic in Indonesia. This happens due to the growth of financing in nine industrial sectors, especially the agricultural and fisheries sectors. In addition, this indicates that the policy issued by each of the banking regulator effective enough to drive positive performance of the banking especially in the aspect of financing supply. However, Islamic banking behave very carefully against the distribution of financing to its customers amid the COVID-19 pandemic, which is full of risks.

\subsection{Recommendation}

Based on the results and analysis above, it can be proposed some recommendations for practitioners, regulators and academicians. COVID-19 pandemic not always has a negative impact for the banking industry, but also has a positive impact including the acceleration of digital banking at Islamic banks. Then, for Islamic banks expected to accelerate digital banking that have a positive impact for the business of the bank. For the regulator, the COVID-19 pandemic is a problem of multidimensional that can be solved by means of synergy and collaboration. The banking regulator should be able to strengthen the synergy among institutions. For academicians, researcher realized that this study is still a shortage of some of the research limitations in data and the variables used. The next researcher can conduct study with similar topics by adding variables both internal variables (financial performance of banks) and external variables (macroeconomic) to be able to provide the results of the study more comprehensive. In addition, the upcoming researchers can also compare between Islamic banks and conventional banks in the aspect of financing supply.

\section{References}

Alkhazaleh, A. M. K. (2017). Factors may drive the commercial banks lending: evidence from Jordan. Banks and Banks System. 12(2), 31-38.

Altavilla, C. et al. (2018). Credit supply and demand in unconventional times (Working Paper Series 2202). European Central Bank.

Bank Indonesia. (2020). Bersinergi membangun ekonomi \& keuangan syariah. Laporan Ekonomi \& Keuangan Syariah 2020. Retrieved 16 May, 2021, from https://www.bi.go.id/id/LEKSI-2020/default.aspx

Bank Indonesia. (2021). Sinergi kebijakan untuk menjaga ketahanan sistem keuangan dan mendorong intermediasi dalam rangka pemulihan ekonomi. Kajian Stabilitas Keuangan, 36(2021). Retrieved 16 May, 2021, from https://www.bi.go.id/ksk36/default.aspx

Barua, B., \& Barua, S. (2021). COVID-19 implications for banks: evidence from an emerging economy. SN Business \& Economics, (2021), 1-28.

Busmante, J., Cuba, W., \& Nivin, R. (2019). Determinants of credit growth and the bank lending channel in Peru: a loan level analysis (BIS Working Papers 803). Bank for International Settlements.

Chernykh, L., \& Theodossiou, A. K. (2011). Determinants of bank long-term lending behavior: evidence from Russia. Multinational Finance Journal, 15(3/4), 193-216. 
Çolak, G., \& Öztekin, Ö. (2020). The impact of COVID-19 pandemic on bank lending around the world. (October 15, 2020). Available as SSRN: https:/ssrn.com/abstract $=3712668$

Hasan, I., Politsidis, P. N., Sharma, Z. (2020). Bank lending during the COVID-19 pandemic (Munich Personal RePec Archive 103885).

Imran, K., \& Nishat, M. (2018). Determinants of bank credit in Pakistan: a supply side approach. Economic Modelling, 35(2013), 384-390.

Malede, M. (2014). Determinants of commercial banks lending: evidence from Ethiopian commercial banks. European Journal of Business and Management, 6(20), 109-117.

Manaresi, F., \& Pierri, N. (2018). Credit supply and productivity growth (BIS Working Papers 711). Bank for International Settlements.

Nachrowi, D. N., \& Usman, H. (2018). Pendekatan Populer dan Praktis Ekonometrika untuk Analisis Ekonomi dan Keuangan. Jakarta: Lembaga Penerbit Fakultas Ekonomi Universitas Indonesia.

Sumantri, M. B. A., \& Yudawisastra, H. G. (2019). The influence of macroeconomic factors toward stock's return. International Journal of Innovation, Creativity and Change, 6(7), 107-117.

World Bank. (2020). The economic and social impact of COVID-19. Western Balkans Regular Economic Report, 17(2020). Retrieved 16 May, 2021, from https://documents.worldbank.org/en/publication/documentsreports/documentdetail/457181588085856454/the-economic-and-social-impactof-covid-19-the-country-note 